\title{
Incomprehensive Understanding About Mohammed; A Critic Over Orientalist
}

\author{
Deva Alvina Br Sebayang \\ Penyuluh Agama Kristen Kemenag Kota Medan \\ email:dee_bayanc@yahoo.co.id
}

\begin{abstract}
This paper aims to reveal orientalism and how single story about Muhammad has been created. Single story created stereotype which containing the truth, but it was incomprehensive ways or unfinished story.According to Diechie, single story is a way to tell and portray something monolithically. Single story is related to tendency of human centered for seeing that she is better than other.There are no possibilities to look at the other as equal and connected with them. The other has assumed as an alien that is totally different and has no possibilities to be connected with them. This paper also describes debate between Edward Said and Bernard Lewis and Richard King about orientalism. These scholars are coming from different background but having shared point of view about orientalism.
\end{abstract}

\section{Keywords}

Single story, orientalism

\section{Introduction}

As a non-Muslim, I inherited a bad story about Islam from my parent and my religious teacher. My parent prefers to turn off television when Azan Maghrib is showed in TV. The portrayal about Islam, as I perceived, was arrogant and full of war, and also about God who has many wives. Otherwise, the teacher of Sunday school also told about the burning of churches and the murder of pastors in remote area. In my memory, the face of Islam was full of violence. It is not only me who inherited bad story 
about other religions; it almost happened in all religious communities. The parents and religious leaders inherited the bad stories about other religions to their son and young generation. Islamic generation was also inherited a bad story about Christian; it was also the generation from other religions. The stories about them influences the ways they did socialization and chose friends, the shyness could be as mocking.

The bad story about the others is coming from single story. A writer and poet from Africa, Chimamanda Ngozi Adichie, argued that the story has power, but human is always only having one single story. Single story created stereotype which some time contains the truth, but it is incomprehensive ways or unfinished story.

Single Story about Islam in my memories was even worse when I was adult. Although in reality I have beautiful friendship with Muslim in my undergraduate program, but I was never interested in Islam. In Indonesia, Islam is close to power and politic, and tends to trigger violence. The story about burning church that once closed is now opened and exposed on television screen. Exclusivity of religious community and acts of violence perpetrate label as Islamic Organizations increasingly imbed Islam as violence in the identity of my single story.

International world also has single story about Islam, terrorist movements labeling Islam also worsen the story about Islam. Although a lot of people deny ISIS as part of Islam, but it is undeniable that it is also part of Islam face. A Single Story about Islam appears as Islam phobia in Europe and America. The rising of Islam Phobia in political realm is not only in America. European countries one by one falls in religious extremist; starting from the rising voice of Perussuomalaiset party in Finlandia, Liberal Leadership party in Holland leads by Gert Wilders, Ukip in England or FPO in Austria. Similarly in German, an alternative party for German, AFD, for the first time raised the voice two times in the national debate. It made Donald Trump used rhetorical of Islam Phobia 
in his campaign and stated that he would close all the gates for Muslim migrants in America.

Single story about Islam is not a new concept even from ISIS, or Al-Qaeda movement. Esposito says that many Westerners see Islam in terms and stereotypes Jihad and religious extremists (Esposito 2006, 200). In religious studies, it can be understood that there are long history about Islam, single story about Islam is understood as small part of Orientalism in understanding civilization in eastern. This paper is a final paper for World Religion class, because Islam has board definition, this paper focuses on the figure of Muhammad as founding father of Islam. This paper is aimed to reveal what is Orientalism and how single story about Muhammad has been created.

\section{Danger of Single Story}

\section{Single Story Definition}

Chimomanda Dichie is a storyteller from Africa, she has presented about the Danger of Single Story. In the beginning, she began her story with her interest in reading children novels from America and British. Besides reading, she also drawing, the character drawn is a blonde, blue eyes and playing snow. From her story, it can be concluded that Dichie has big contribution for imagination and human memories. The character she read when she was a child looked alive in her mind. It made strange figure became natural and real. The story that she read had stirred her imagination.

According to Dichie, Single story is a way to tell and portrays something monolithically. Single story is related to tendency of human, centered for them and seeing that she is better than others. There is no possibility for looking others as equal and connected with them. Another is an alien that is totally different and has no possibilities to be connected with them. 
As an example, Dichie said about single story of Africa coming from western literature, Jhon Locke. Jhon Locke is an England man sailing to West Africa in 1561. A quote from John Locke said that Black Africans are as beasts who have no houses. They are also people without heads, having their mouth and eyes in their breasts". In the 1561, surely it is hard for conducting long trip. It is only trader, researcher and ruler who can do it easily. The role of writing or characterizing from those who are able for trip is big. The first writing of John Locke becomes a tradition in how they describe people of West Africa in western countries.

Africa in western countries has been known as the dark place, scary and wholly different from others. Africa is represented as an area inhabited by horrible community, uneducated and strange. Perpetual stories become standard of truth. Slowly, the story from John Locke becomes tool of measurement of "authenticity" of Africa. Dichie told that she wrote a novel about Africa, her lecturer said that her novel did not represent the authenticity of Africa. Indeed, for Diechie, as an African, she could not see the authenticity of African. African is beautiful area with many nations inhabiting that land. Thus, it is impossible to describe Africa with measurement of authenticity and how single story creates someone or something as a single character. Meanwhile, everything has its own complexity.

Why single story is dangerous for Diechie? There is tendency that single story is related to the power. Diechie said that "Power is the ability not just to tell the story of another person, but to make it the definitive story of that person. The consequence of the single story is this: It robs people of dignity. It makes our recognition of our equal humanity difficult. It emphasizes how we are different rather than how we are similar”. As it is mentioned that the tendency in building the image for recognizing that they are better or recognizing others in their image meanwhile, the image containing testimony of definitive story needed by human. The danger 
is when the storyteller has power syndrome related to their stories. Thus, the telling tends to judge by using their own perspective, not as equal as human about understanding the difficulties of life. Finally, the danger of single story is in the emphasizing about the different, not in the similarities.

Interestingly, the theory about single story is also containing the truth, but it is not complete or unfinished story. The big mistake is when there is no tendency to continue the process and stuck in the single story. There is no interaction process, discussion, continuing process or revisiting the exits stories.

\section{Orientalism Definition}

This paper is written with passion to know Islam deeply. The writer realizes that after passing first semester in religious studies, there was 'single story' about Islam inherited to her. It seems that it is unfair if she does not check that memory. The keyword that she found is Orientalism. In the beginning, orientalism used for two realms, first in art college-that of a group of artists, mostly from Western Europe, who visited the Middle East and North Africa and depicted what they saw or imagined, sometimes in a rather romantic and extravagant manner. The second and more common meaning, unconnected with the first, has been a branch of scholarship (Said 1982).

Regarding the definitions of orientalism, there are a lot of debates among academia. The most interesting is the debate between Edward Said and Bernard Lewis and Richard King. These scholars are coming from different backgrounds but having shared point of view about Orientalism.

\section{A. Orientalism in the Perspective of Edward Said}

Orientalism in academically is indoctrinating orient and oriental as Edward Said (1982) said his book Orientalism. He is a Palestinian, studied in Egypt but in the early of his age he moved to America. Edward took 
English and Comparative literature in Harvard University. According to Edward, orientalism is western style in dominating, reconstructing and authoritative over orient. The meaning of orient here is civilization, value and eastern culture, while occident is everything related to western. Occident in technology and literature are more advance than orient. Otherwise the reality that western colonization over eastern can't be denied. The story about eastern can't be replaced from western's view over eastern.

Orientalism is the way of thinking based on ontological and epistemological perspective. Western tends to see eastern based on the stories in their academic writing. Western in the beginning has created the authenticity of orient based on their telling pattern that can't be replaced from their power syndrome. The telling about Orientals cased the gap between oriental and occidental. Oriental has its own history and its own tradition. Orient is not about the story orientalist. Based on Vico, "based on observation that men make their own history, that what they can know is what they made and extends it to geographical. Orient and Occident are manmade". The term orient and occident is western product for mapping civilization based on geography. The differentiation and stories created polarization between western and eastern.

According to Said, translating book done by orientalist is not only translation, but the depiction about 'conquering' which brings the world into historical moment namely colonialism and imperialism (65). One of example is about the story of "Thousand and one night" translated in France by Antoine Galland (Le mille et une nuits). It told about Arabian countries with genie and magic world. The relationship between occident and orient is a relationship of power, of domination of complex hegemony. Orientalisme is western single story about eastern civilization in academic world. 


\section{B. Orientalism in the perspective of Bernard Lewis}

Said's understanding about orientalism is much questioned by Lewis. Bernard Lewis is British-American historian specializing in oriental studies. He is also known as a public intellectual and political commentator. According to Bernard the term Orientalist is already polluted. "What did the word mean before it was poisoned by the kind of intellectual pollution that in our time has made so many previously useful words unfit for use in rational discourse?" Orientalism than is horrible word for scholars, that pollution has decreased the value of orientalism.

Two things criticized by Lewis are about:

The naming of the Orient or Arabian is as polarization process between West and East. Lewis explains that the naming occurred because of the increasing of complex knowledge to make it easier, orient to describe the area that they were studying, the so-called Orient, was seen to extend far beyond the Middle Eastern lands on which European attention had hitherto been concentrated, and to include the vast and remote civilizations of India and China.

In addition, it was accidentally making the last-named term, e.g. Arabist, has also gone through a process of re-semanticization. The aim to denote a scholar professionally concerned with the language, history, or culture of a particular land and people. The creation of the term or the naming was not created to create the distance but was created because of the more complex knowledge due to the changing times.

The word Orientalist already contains the sensitivity of identity. Said's Critics against the West is about generalizing approach that all orientalists are bad with the aim of colonialism. For Lewis, not all Orientalists come from the State of colonialism, and then Lewis exemplifies the Germany orientalist who has a lot of study of the Eastern world, but absolutely not a colonial State. Lewis (1982) also disagrees with Said's approach which is against the structure of the result works of Oriental 
studies. The last is what Lewis said that in the beginning, the expert or philologists concerned with the recovery, study based on publication and interpretation of texts. It is not like nowadays, that the main source for academic research is the literature that already exists.

Pro and contra about orientalist definition mediated by Richard King. Richard King is a Professor of Buddhist and Asian Studies at the University of Kent, where he specializes in South Asian traditions and critical theory and Religious Studies. Richard King helps to understand what orientalism is. If Said emphasized that orientalism is part of western colonial-ization over eastern in academic, Lewis concerns on how the word orientalist has been created. King saw orientalism has been created as the process of mystical genealogy definition and the failure of western in understanding the eastern.

\section{Definition of Orientalism from Richard King}

Orientalism is the way of depiction eastern by western that dominated with lens and western paradigm. Thus according to Richard King (2013), the failure of orientalism as follow:

1. The example is the failure in depicting the mystical genealogy. The source of that failure is western thinking that is much influenced by enlightened era. The enlighten period brought the gap between secular world and religious world, public and private the assumption is that religious privatization will be the power of modern community. Mystic is private and personal and being modern is being leaving mystic behind.

2. Using the word "World Religion" by western scholar constructed from Christian perspective. King articulated that the idea of 'worldreligions' is constructed from the Christian perspective, reliant on a text by which all doxy can be determined (66). As an impact, the religion of Hindu changed as monolithic religion "Hinduism" 
3. Orientalism reflects political power relations between the West and Asia as the institution by which the West dominates and maintains authority over the East (83). When Western scholars identify their work as postcolonial, they free themselves from blame and complicity with colonial and imperial powers (187). Within Subaltern Studies, King identifies vast dichotomies that perpetuate a misrepresentation of the Indian reality. The contemporary Indian context must be seen neither as a product of their own doing nor as the passive pawn of hegemonic Western powers (191)

\section{The Danger of Orientalism Single Story about Muhammad}

\section{Some Single Stories about Muhammad}

Due to the broadest understanding about Orientalism, the depiction chosen is the portrayal about Muhammad in Christian understanding. The background of this paper is also the curiosity of the writer about the source of memory about the figure of Muhammad in the Islamic depiction.

From Wikipedia, we can find the critic of protestants over Muhammad figure. The earliest (documented) Christian knowledge of Muhammad stems from Byzantine sources, written shortly after Muhammad's death in 632. In the Doctrina Jacobi nuper baptizati, a dialogue between a recent Christian convert and several Jews, one participant writes that his brother "wrote to [him] saying that a deceiving prophet has appeared amidst the Saracens". Another participant in the Doctrina replies about Muhammad: "He is deceiving. For do prophets come with sword and chariot? You will discover nothing true from the said prophet except human bloodshed"(wikipedia.org/wiki/Criticism_of_Muhammad) 


\section{Christian critics of Muhammad}

\begin{tabular}{|c|c|c|}
\hline $\begin{array}{l}\text { A f t e r } \\
\text { Muhammad's } \\
\text { death in } 632 \text {. }\end{array}$ & $\begin{array}{l}\text { Muhammad: "He is deceiving. } \\
\text { For do prophets come with } \\
\text { sword and chariot?, }\end{array}$ & $\begin{array}{l}\text { Walter Emil Kaegi, Jr., "Initial } \\
\text { Byzantine Reactions to the Arab } \\
\text { Conquest", Church History, Vol. } \\
38 \text {, No. } 2 \text { (Jun., 1969), p. 139- } \\
\text { 149, p. 139-142, quoting from } \\
\text { Doctrina Jacobi nuper baptizati } \\
\text { 86-87 }\end{array}$ \\
\hline 676-749 AD & $\begin{array}{l}\text { Arian monk (whom he did not } \\
\text { know was Bahira) influenced } \\
\text { Muhammad and the writer } \\
\text { viewed the Islamic doctrines as } \\
\text { nothing more than a hodgepodge } \\
\text { culled from the Bible }\end{array}$ & $\begin{array}{l}\text { The second chapter of his book, } \\
\text { The Fount of Wisdom, titled } \\
\text { "Concerning Heresies" }\end{array}$ \\
\hline 9th century & $\begin{array}{l}\text { Álvaro of Córdoba Muhammad } \\
\text { the Antichrist.[10] Since the } 7 \text { th } \\
\text { century, Muhammad and his } \\
\text { name have been connected to } \\
\text { several stereotypes }\end{array}$ & $\begin{array}{l}\text { Kenneth Meyer Setton (July 1, } \\
\text { 1992). "Western Hostility to } \\
\text { Islam and Prophecies of Turkish } \\
\text { Doom". DIANE Publishing. } \\
\text { ISBN 0-87169-201-5. pg 4-15 }\end{array}$ \\
\hline \multicolumn{3}{|l|}{$\begin{array}{l}\text { M I D D L E } \\
\text { AGES }\end{array}$} \\
\hline \multirow[t]{2}{*}{$\begin{array}{l}\text { During the } \\
\text { 12th century }\end{array}$} & $\begin{array}{l}\text { Peter the Venerable, Saw } \\
\text { Muhammad as the precursor } \\
\text { to the Anti-Christ and the } \\
\text { successor of Arius,[10] }\end{array}$ & $\begin{array}{l}\text { Kenneth Meyer Setton (July 1, } \\
\text { 1992). "Western Hostility to } \\
\text { Islam and Prophecies of Turkish } \\
\text { Doom". DIANE Publishing. } \\
\text { ISBN 0-87169-201-5. pg 4-15 }\end{array}$ \\
\hline & $\begin{array}{l}\text { Martin Luther viewed } \\
\text { Muhammad as "a devil and first- } \\
\text { born child of Satan }\end{array}$ & $\begin{array}{l}\text { Mohammed } \\
\text { Mohammedanism", } \\
\text { Encyclopedia, 1913 }\end{array}$ \\
\hline 20th-century & $\begin{array}{l}\text { In the early 20th century Western } \\
\text { scholarly views of Muhammad } \\
\text { changed, including critical views }\end{array}$ & \\
\hline
\end{tabular}




\begin{tabular}{|l|l|l|}
\hline 19th-century & $\begin{array}{l}\text { Western scholars such as Aloys } \\
\text { Sprenger, Theodor Noldeke, } \\
\text { Gustav Weil, William Muir, } \\
\text { Sigismund Koelle, Grimme } \\
\text { and D. S. Margoliouth "give us } \\
\text { a more correct and unbiased } \\
\text { estimate of Muhammad's life } \\
\text { and character, and substantially } \\
\text { agree as to his motives, prophetic } \\
\text { call, personal qualifications, and } \\
\text { sincerity. }\end{array}$ \\
\hline
\end{tabular}

From the explanation above, the single story about Muhammad has long history and inherited up to now. It is a single story about Muhammad as false prophet, as a man of violence, and his morality is questioned because he has a lot of wives.

Professor Hamka, a clergyman, a philosopher and Islamic thinker in Indonesia in his introduction to Muhammad Haikal book, stated that Islamic literature was robbed with the infiltration of orientalism. It is not only from western, but also scholar educated in western style (Haekal, 1995). One of neutral book is written by Muhammad Haikal about history of Muhammad. In his book, Haikal realized that there are many factors in arising single story about Muhammad. One of them is oral tradition in the Middle East which makes the others hardly understood in understanding Islamic holy book. The different teaching, geographical context and also spirit of colonialism from western, actually Islam has no problem with Christianity. Islam also recognizes Isa Almasih (Jesus). The problem is in the power and eastern civilization, and Christianity does not recognize the prophet hood of Muhammad.

\section{B. The Danger of Orientalism Single Story}

According to Dichie, Single story is very dangerous because;

1. Being the measurement of the authenticity of the object for others. 
Single story inherited continuously about Muhammad became the authenticity or who is Muhammad for others. On the other hand, the magnitude of man's curiosity is not matched by the will to research so that there are many people of other faiths who base the figure of Muhammad on a single story that they inherit.

2. There is no doubt about the human tendency relation of subordination. The relationship between the subject and the object is not subject to subject. Establishment of Single story can not be separated from relations of subordination. Although Bernard Lewis refused, but a long history of conflict between Christians and Islam can not be denied. The long history of Crusade conflict (10951291) history of colonialism can not be denied in the telling about Orientalist. Historical memory is still strong and caused sensitivity to religious communities. Denying history is equal to fertilize or collecting weapons to suddenly detonated. in storytelling about Muhammad deeply felt the relation of subordination, may be associated with comparative religious doctrine or Science.

3. Human action driven by his imagination, Single story becomes the basic of human's imagination. Let us say that my previous understanding that the figure of the Prophet Muhammad is someone who loves power and violence as well; a Prophet who has many wives. In conclusion, there is nothing interesting in the figure of Muhammad. That conclusion stops my interest to know more about Islam. Especially when I often meet some Muslims who were proud and felt belong to the Indonesian state. The more dangerous, Single Story is associated with Terrorist acts or ISIS lately. These symptoms occur on awakening Islamophobia in European countries and America, so Donald Trump said that he will close the door for Muslims to America. Whereas the figure of Muhammad is falsely represented and happened in a long time and there is no conection 
with arrogance of majority because in many places, the majority tends to be arrogant to the minority. Lastly, ISIS is not an act that is based on the ideals of Islam but rather on the interests of its leader alone. This is very dangerous because in Indonesia, Muslims and Christians are living together .

4. Besides the danger of Single Story of Muhammad, I think it is also very dangerous, the single story that spreads about Orientalism by Edward Said. Accusation of political conspiracy in academic theory. Allegations that the Orientalist intentionally colonises knowledge or academic theory . Allegations that Orientalist is a form of colonialism West to East in the form academic theory. It could be and indeed there is an influence in relationship of subordination telling the story of Orientalism before the 20th century, but no change thereafter. If the debate in the process of this knowledge is withdrawn directly in political activity it will be very dangerous.

Especially considering that the academic theory underlying the academic activity, which has very big influence towards life. The movements of the world born in the activity of the intelligentsia, for example Mahatma Ghandi, Martin Luther King, Hasan Al Bhana, etc. National Movement in Indonesia appears from the educated academics and reformation of Indonesia driven by student activists. Ideals championed by founding father produced academic theory in college. For that I agree with the concept of Dichie's "SINGLE STORY" that there can be truth but likely also false, the story is not yet over and the final that takes the process to correct the truth.

\section{Conclusion}

\section{Reconstruction of Single Story of Muhammad}

The process that happened to me is also happened to orientalist, regardless of the influence of history. Austrian philosopher Karl Popper 
stated that the truth of a scientific theory cannot be proved forever. It is a human product that can be challenged when there are other people who come up with a better theory and almost approaching the truth (Said, 1995): Science is a human products to understand what is happening in his life. Highly rapid development happen in human life. Orientalism is a result of western science to understand civilization, territories, human, living systems from the east. Western philosophy is based on ontologies and epistemology. The fundamental question at the heart of western philosophy is "Is the essence of everything that exists? (Ontology) and "How can we know it? If we can "(Epistemology) Error perception occurs because when the Orientalist approach based Textual approach according to Lewis. Science is nothing perfect, there is always a thesis, antithesis and synthesis of theory been there before (Magee, 2008). Science associated with the development of human. Suppose that in the history of western philosophy, in the period of ancient Greece theory has only been tested by discussion only. In the beginning period of science, the theory was tested with confronts the reality and size directly. On philosophy period 20th century context of the human condition and the universe is no longer understood as God's creation. Then the interest is more on logic and analysis language. Science developments of the 20th century forcing human to reassess the nature human knowledge.

Sayyed Nasr is an Iranian University Professor of Islamic studies at George Washington University, and an Islamic philosopher. He realized that misunderstanding the story of Muhammad in Western Christianitylasted over the centuries. Muhammad is often compared or equated with Jesus, Muslims are followers of Muhammad. According to Nasr, understanding Islam should dotted foot in Islam tradition (Nasr, 2000). Muhammad is not a god, he is a perfect man. In a different book, Ideals and realitites Islam, Nasr explains that there is a misunderstanding about the role of the Prophet Muhammad. The tendency to understand 
by comparing makes people outside of Islam misunderstood. Rests of other religions, A spiritual leader of more guides on the spiritual, worship is not part of politic affairs (Nasr 2000, 58).

In the Qur'an, (QS Ali'Imran [3]: 81)

"And remember when Allah took the covenant and the Prophets, 'It's what I have given you in the form of books and wisdom, then come unto you a Messenger (Muhammad) who justify you, surely you really going to believe him and help him. ' God said, 'Do you recognize and accept my covenant is this? 'They answered' we are admitted'.

Then it is a mistake or misunderstanding by studying other religions from the religious affiliations. But it is not that all Orientalists tell the ugliness of the Prophet Muhammad, is it?. Even there are many people who find and communicate that the Prophet Muhammad is excellent.

Washington Irving (1889, 192-3, 199) Well-known as the "first American man of letters, "revealed the figure of Muhammad: ??

"He was sober and abstemious in his diet, and a rigorous observer of fasts. He indulged in no magnificence of apparel, the ostentation of a petty mind; neither was his simplicity in dress affected, but the result of a real disregard to distinction from so trivial a source ... In his private dealings he was just. He treated friends and strangers, the rich and poor, the powerful and the weak, with equity, and was beloved by the common people for the affability with which he received them, and listened to their complaints ... His military triumphs awakened no pride nor vain glory, as they would have done had they been effected for selfish purposes. In the time of his greatest power he maintained the same simplicity of manners and appearance as in the days of his adversity. So far from affecting regal state, he was displeased if, on entering a room, any unusual testimonial of respect were shown to him."

Prophet Muhammad is someone who was well behaved and loving companions, family as well as strangers. He was someone who did not look at others from their wealth or office. As a person who has respected 
positions, Muhammad was a figure who was not obsessed to be respected, he was very humble and open minded.

Besides Irving who is the Father of American literature, Sir William Muir was an Orientalist and scholar of Islam. His chief area of expertise was the history of the time of Muhammad and the early Caliphate.

"He enhanced each in his own work, and his habits are not reaching anything if it does not really exist in his presence. Likewise, his habit in the association in middle of the community when he was talking with someone while staring at his face, he was not facing him with half face but with all my face and body facing him and with serious attitude to him. While shake hands, he did not let go of the hand before others release his hand. So are when he chatted with strangers do not leave it in the middle of the conversation nor ear turned away of them. He is live a full life with simplicity. His habit is when need something, he would do with his own hands. When giving alms, he gave it with his own hands directly to beggars. He helped his wives in household work ... Delegates and guests who come from outside the area, he greeted with welcoming and cheerful faces while saying welcome to them with respect and affection. He is very easy to be informed like the river flows towards the edge. In welcoming the arrival of the delegation and in solving judge actions of other governments can proved from history that in Muhammad [s.a.w.] knotted all the perfect ability and discretion. Of all cases surprising is that he can not writing (Haekal, 1995).

Connectivity of humans today is not as difficult as the time of the early Orientalist. Digital era has made easy conectivity of people who live in the planet Earth. Every human around the world will be connected as long as it has the internet facility ${ }^{8}$. Connectivity speeds up communication and facilitates communication's reconstruction of the story or paradigm. Resurrection of digitization library gives good results in this era, giving major contribution to address the realities of distance and limited economic case for traveling. With the many resources found in Internet then we could check the single story about another, about 
other regions or about other cultures. With hopes of connectedness, we can reconstruct a single story about another. Although we are far stretched distance but through the internet we can see the complexity of life, equality of humanity with others, their beauty on the others, the truth of the other sides. The orientalist's initial error in the telling about Muhammad will be very dangerous, slowly but eventually acknowledged and rectified by the Orientalist thereafter. Through writing Final Paper, other than reconstructing the Story of Muhammad in the imagination of my mind, I understand an academic dialogue of the Scholar. Finally, the author is still optimistic that what we are going through is a process of human learning and we still continue going in search of knowledge. The main thing is that we are always open towards reconstruction of single story about the others. 


\section{References}

Adichie, C. 2009. The Danger of A Single Story. TED talks 7.

Ali, Muhammad. 2007. Al -Qur'an Suci Terjemahan dan Tafsir. Darul Kutubil Islamiyah.

Esposito, John L. 2006. World Religion Today. Oxford : Oxford University Press

Haekal, Muhammad Husain. 1995. Sejarah Hidup Muhammad. Jakarta: Litera Nusa.

Irving, Washington. 1889. Life of Mahomet. London : A.L Burt Company, New York

King, Richard, 2013. Orientalism and Religion: Post-Colonial Theory, India and The Mystic East. London : Routledge.

Lewis, Bernard. 1982. "The Question of Orientalism." The New York Review of Books

Magee, Bryan. 2008. The History of Philosophy. Yogyakarta: Penerbit Kanisius.

Nasr, Seyyed Hossein. 2000. Ideals and Realities of Islam, ABC International Group publisher

Nasr, Seyyed Hossein. 2002. The Heart Of Islam, Herper San Fransisco Publisher

Said, Edward. 1995. Orientalism. England: Penguin books.

Schmidt, E. and J. Cohen. 2013. The New Digital Age: Reshaping the Future of People, Nations and Business, Hachette UK.

\section{Website}

http: / / www.dw.com/id / d onald-trump-dan-geliatislamofobia/a-18901413

https://en.wikipedia.org/wiki/Criticism_of_Muhammad 